\title{
GAS CHROMATOGRAPHY-MASS SPECTROMETRY ANALYSIS OF AN ENDANGERED MEDICINAL PLANT, SARCOSTEMMA VIMINALE (L.) R.BR. FROM THAR DESERT, RAJASTHAN (INDIA)
}

\author{
ARORA SUNITA*, MEENA SONAM, KUMAR GANESH \\ Department of Botany, Jai Narain Vyas University, Jodhpur, Rajasthan, India. Email: jnvusunitarora@gmail.com
}

Received: 25 March 2017, Revised and Accepted: 27 May 2017

\begin{abstract}
Objective: Sarcostemma viminale (L.) R. Br. is one of the important endangered medicinal plants belonging to the family Asclepiadaceae. The aim of the present investigation was to determine the possible bioactive phytochemicals from stem of S. viminale (L.) R. Br. using methanol, chloroform, and
\end{abstract} hexane as solvents.

Methods: Plant material was collected from typical conditions of Indian Thar Desert in the month of July-September, 2016. This plant always grows in association with the congeneric plant, Euphorbia caducifolia. The phytochemical compounds were investigated using Perkin-Elmer gas chromatography-mass spectrometry, while the mass spectra of the compounds found in the extract were matched with the National Institute of Standards and Technology library.

Results: Maximum \% area is found for Lup-20-(29)-en-3-yl acetate is present maximum amount (40.85\%) with reaction time (RT)=43.787 minutes, followed by 4, 4, 6A, 6B, 8A, 11, 11, 14B-octamethyl-1, 4, 4A, 5, 6, 6A, 6B, 7, 8, 8A, 9, 10, 11, 12, 12A, 14, 14A, 14B-octadecahydro-2H-picen-3one \$olean-12-en-3-one\# (13.74\%) with RT=44.420 minutes in the methanolic extract; acetic acid 4, 4, 6A, 8A, 11, 12, 14B-octamethyl-1, 2, 3, 4, 4A, $5,6,6 \mathrm{~A}, 6 \mathrm{~B}, 7,8,8 \mathrm{~A}, 9,10,11,12,12 \mathrm{~A}, 14,14 \mathrm{~A}, 14 \mathrm{~B}$-eicosahydro-picen-3-yl ester $\$$ urs-12-en-3-yl acetate is present maximum amount (44.98\%) with RT=48.265 minutes, followed by. beta.-amyrin (18.51\%) with RT=40.580 minutes in the chloroform extract; acetic acid 4, 4, $6 \mathrm{~A}, 8 \mathrm{~A}, 11,12$, 14B-octamethyl-1, 2, 3, 4, 4A, 5, 6, 6A, 6B, 7, 8, 8A, 9, 10, 11, 12, 12A, 14, 14A, 14B-eicosahydro-picen-3-yl ester \$\$ urs-12-en-3-yl acetate is present maximum amount (45.47\%) with RT=48.514 minutes, followed by. beta.-amyrin (19.21\%) with RT=40.555 minutes in the hexane extract of stem of S. viminale (L.) R. Br.

Conclusion: Medicinal plants contain one or more substances that can be used for therapeutic purpose; they are used by the world population for their basic health needs. The importance of the study is to investigate the pinpoint biological activity of some of these compounds so that they can be used by pharma or some other drug designing industry to find a novel drug.

Keywords: Sarcostemma viminale, Phytocomponents, Methanol, Chloroform, Hexane, Gas chromatography-mass spectrometry, Retention time.

(c) 2017 The Authors. Published by Innovare Academic Sciences Pvt Ltd. This is an open access article under the CC BY license (http://creativecommons. org/licenses/by/4. 0/) DOI: http://dx.doi.org/10.22159/ajpcr.2017.v10i9.18707

\section{INTRODUCTION}

Plants are man's friend in survival; providing us food, fuel, and medicine from the days beyond the dawn of civilization [1]. According to the World Health Organization, about $80 \%$ of the world population depends on the natural product for their health due to minimal side effect and cost-effectiveness [2]. The secondary metabolites are a significant source with a variety of structural arrangements and properties [3]. Medicinal plants, as a source of remedies, are widely used as alternative therapeutic tool for the prevention or treatment of many diseases [4]. Natural products which come out from medicinal plants are important for pharmaceutical research and drug development as a source of therapeutic agents. At present the demand for herbal plant products has increased significantly [5] as they do not cause any side effect; hence, they are more protective and safe. Sarcostemma viminale (L.) $\mathrm{R}$. Br. is an important endangered medicinal plant (Asclepiadaceae) with twining or perennial herbs [6]. Sarcostemma is commonly known as moon plant and in veda it is known as "soma." It is a remarkably glabrous, vigorously tangling scrambler and climber, which can produce voluminous plants. The inflorescences are mostly lateral and sessile, rarely on short laterals (peduncles) or terminal [7]. The root is used to cure snake bite and taken as an infusion in dog bite cases in Thar Desert [8]. The dry stem is used as emetic and stem juice mixed with water is given in rheumatism, arthritis, joints pain [9], and stem is also used to cure bone fracture [10].

The aim of this work was to isolate, investigate, and characterize the phytochemical constituents in three different extract, i.e., methanol, chloroform and hexane by using gas chromatography-mass spectrometry (GC-MS) from stem of S. viminale (L.) R. Br. Traditionally used medicinal plants have recently attracted the attention of scientific communities, it has resulted in the isolation and identification of secondary metabolites produced by plants and their use as active principles in medicinal preparations [11]. Phytocompounds from this plant and in-depth study of their biological activity will ensure best possible results in future and open new opportunity for discovery of potential drugs of therapeutic worth [12].

\section{METHODS}

Collection and processing of the plant material

S. viminale (L.) R. Br. was collected from hilly and stony regions of Jodhpur and Udaipur districts of Rajasthan (India) in the month of JuneAugust 2015. The specimen authentication and botanical identification were done by Botanical Survey of India, Jodhpur, Rajasthan.

\section{Qualitative screenings of phytochemicals}

The stem extract of S. viminale (L.) R.Br. was subjected to preliminary phytochemical screening to determine the presence of the various metabolites. Standard analytical procedures were adopted for screening and identification of various phytoconstituents (Table 1).

Fresh stem of S. viminale (L.) R. Br. was collected from nature. The stem was shade dried and prepared to powder in a mechanical grinder. Required powder of $5 \mathrm{~g}$ was weighed separately using an electronic balance and transferred to round bottom flask and extracted with 
$200 \mathrm{ml}$ of selected solvents such as methanol, chloroform, and hexane; boiled at $60-70^{\circ} \mathrm{C}$ for $16 \mathrm{hrs}$ on water bath; filtered, collected and evaporated to dryness, the final residue obtained was then subjected to GC-MS analysis and stored at $4^{\circ} \mathrm{C}$ for further use.

\section{RESULT AND DISCUSSION}

Herbal medicine represents one of the most important fields of traditional medicine worldwide. Various extracts from traditional medicinal plants have been tested to identify the source of the therapeutic effects. Significance of employing bioactive compounds in pharmacy to produce drugs for the treatment of many diseases requires purification of compounds [13]. The preliminary phytochemical screening of stem extract of $S$. viminale (L.) R. Br. was carried out using three solvent, i.e., methanol, chloroform and hexane. The analysis revealed the presence of various secondary metabolites, i.e., alkaloids, carbohydrates, glycosides, phenolic compounds, flavonoids, proteins, amino acid, saponins, sterols, acidic compounds, and terpenoids with important biological activities (Table 1). Secondary metabolites by chromatography and spectroscopy provide valuable information about the qualitative and quantitative formulation of plant species [14].
The combination of the best separation technique (GC) with the best identification technique (MS) made GC-MS an ideal technique for qualitative analysis for volatile and semivolatile bioactive compounds [15]. GC-MS analysis of the stem of $S$. viminale (L.) R. Br. in different solvent such as methanol, chloroform, and hexane showed 70, 72 and 61 peaks (Figs. 1-3) indicating the presence of 64, 56 and 47 compounds in respective extracts. Confirmation of the presence was based on retention time (RT), peak area, molecular formula, concentration (\%), and molecular weight (Tables 2-4).

LUP-20-(29)-en-3-YL acetate is present in maximum amount (40.85\%), followed by 4, 4, 6A, 6B, 8A, 11, 11, 14B-octamethyl-1, 4, 4A, $5,6,6 \mathrm{~A}, 6 \mathrm{~B}, 7,8,8 \mathrm{~A}, 9,10,11,12,12 \mathrm{~A}, 14,14 \mathrm{~A}, 14 \mathrm{~B}$-octadecahydro2H-picen-3-one\$ \$olean-12-en-3-one\# (13.74\%) and hexadecanoic acid, methyl ester $(0.03 \%)$, oxalic acid, cyclohexylmethyl tridecyl ester $(0.04 \%)$, 13-docosenamide, (Z-) (0.05\%) were present in minimum amount in the methanolic extract; acetic acid 4, 4, 6A, 8A, 11, 12, 14B-octamethyl-1, 2, 3A, 5, 6, 6A, 6B, 7, 8, 8A, 9, 10, 11, 12, 12A, 14, 14A, 14B-eicosahydro-picen-3-YL ester \$ WRS-12-en-3-YL acetate is present maximum amount (44.98\%), followed by. beta.-

Table 1: Phytochemical constituents of the stem extract of Sarcostemma viminale

\begin{tabular}{|c|c|c|c|c|c|}
\hline S.No. & Phytoconstituents & Tests & Methanol & Chloroform & Hexane \\
\hline 1. & Alkaloids & Wagner's test & +++ & +++ & ++ \\
\hline 2. & Carbohydrates & Molisch's test & +++ & + & + \\
\hline 3. & Glycosides & Borntrager's test & - & - & - \\
\hline 4. & Phenolic compounds & Lead Acetate test & +++ & ++ & + \\
\hline 5. & Flavonoids & Alkaline test & +++ & ++ & - \\
\hline 6. & Protein and amino acid & Xanthoprotein test & +++ & ++ & ++ \\
\hline 7. & Saponins & Foam test & +++ & - & ++ \\
\hline 9. & Acidic compounds & & +++ & ++ & - \\
\hline 10. & Terpenoids & Salkowski test & + & - & - \\
\hline
\end{tabular}

-: Absent, +: Present, ++: Moderately present, +++: Abundantly present

Table 2: Bioactivity of phytocomponents identified in methanol extract of stem of Sarcostemma viminale

\begin{tabular}{|c|c|c|c|c|c|c|}
\hline S.No. & RT (minutes) & Name of compound & $\%$ area & $\begin{array}{l}\text { Molecular } \\
\text { formula }\end{array}$ & $\begin{array}{l}\text { Molecular } \\
\text { weight }\end{array}$ & Biological activity \\
\hline 1. & 7.137 & 2,3-dihydro-3,5-dihydroxy-6-methyl-4H-Pyran & 0.22 & $\mathrm{C}_{6} \mathrm{H}_{8} \mathrm{O}_{4}$ & 144 & Antimicrobial, anti-inflammatory \\
\hline 2. & 7.857 & Benzoic acid & 1.91 & $\mathrm{C}_{7} \mathrm{H}_{6} \mathrm{O}_{2}$ & 122 & $\begin{array}{l}\text { Used as an expectorant and } \\
\text { fungal skin diseases, analgesic, } \\
\text { food industry, antifungal } \\
\text { properties }\end{array}$ \\
\hline 3. & 9.631 & 2-methoxy-4- & 0.05 & $\mathrm{C}_{9} \mathrm{H}_{10} \mathrm{O}_{2}$ & 150 & Antibacterial \\
\hline 5. & 13.857 & 1,3,4,5-tetrahydroxy-cyclohexanecarboxyl & 0.32 & $\mathrm{C}_{7} \mathrm{H}_{12} \mathrm{O}_{6}$ & 192 & $\begin{array}{l}\text { Antimicrobial, } \\
\text { anti-inflammatory, antioxidant } \\
\text { activity }\end{array}$ \\
\hline 6. & 15.035 & $\begin{array}{l}\text { 4-((1E)-3-hydroxy-1-propenyl)- } \\
\text { 2-methoxyphenol }\end{array}$ & 0.12 & $\mathrm{C}_{10} \mathrm{H}_{12} \mathrm{O}_{3}$ & 180 & $\begin{array}{l}\text { Antimicrobial, antioxidant, } \\
\text { anticancer, anti-inflammatory } \\
\text { activity }\end{array}$ \\
\hline 8. & 16.717 & Hexadecanoic acid, methyl ester & 0.03 & $\mathrm{C}_{17} \mathrm{H}_{34} \mathrm{O}_{2}$ & 270 & $\begin{array}{l}\text { Antibacterial and antifungal, } \\
\text { antioxidant hypocholesterolemic, } \\
\text { nematicide, insecticide lubricant, } \\
\text { antiandrogenic flavor, hemolytic }\end{array}$ \\
\hline 9. & 18.123 & Heptadecanoic acid & 0.13 & $\mathrm{C}_{17} \mathrm{H}_{34} \mathrm{O}$ & 270 & $\begin{array}{l}\text { Antioxidant, antifungal, } \\
\text { surfactant }\end{array}$ \\
\hline 10. & 27.483 & 13-docosenamide, (Z)- & 0.05 & $\mathrm{C}_{22} \mathrm{H}_{43} \mathrm{NO}$ & 337 & Antimicrobial activity \\
\hline 11. & 39.249 & Stigmast-5-en-3-ol, (3.beta.)- & 3.03 & $\mathrm{C}_{29}^{22} \mathrm{H}_{50}^{43} \mathrm{O}$ & 414 & $\begin{array}{l}\text { Anti-inflammatory, anti-pyretic, } \\
\text { anti-ulcer, antiarthritic }\end{array}$ \\
\hline 12. & 40.459 & Alpha.-amyrin & 7.32 & $\mathrm{C}_{30} \mathrm{H}_{50} \mathrm{O}$ & 426 & $\begin{array}{l}\text { Antioxidant, antimicrobial, } \\
\text { anticancer, anti-inflammatory }\end{array}$ \\
\hline
\end{tabular}

RT: Reaction time 
Table 3: Bioactivity of phytocomponents identified in the chloroform extract of stem of Sarcostemma viminale

\begin{tabular}{|c|c|c|c|c|c|c|}
\hline S.No. & RT (minutes) & Name of compound & $\%$ area & $\begin{array}{l}\text { Molecular } \\
\text { formula }\end{array}$ & $\begin{array}{l}\text { Molecular } \\
\text { weight }\end{array}$ & Biological activity \\
\hline 1. & 11.109 & Caryophyllene & 0.02 & $\mathrm{C}_{15} \mathrm{H}_{24}$ & 204 & $\begin{array}{l}\text { Antioxidant, anti-inflammatory, } \\
\text { antibacterial, analgesic, } \\
\text { antitumor activity }\end{array}$ \\
\hline 2. & 14.061 & .Alpha.-cadinol & 0.03 & $\mathrm{C}_{15} \mathrm{H}_{26} \mathrm{O}$ & 222 & $\begin{array}{l}\text { Anti-fungal, drug-resistant } \\
\text { tuberculosis properties }\end{array}$ \\
\hline 3. & 15.830 & $2,6,10$, trimethyl, 14 -ethylene-14-pentadecene & 0.04 & $\mathrm{C}_{20} \mathrm{H}_{38}$ & 278 & Antiproliferative \\
\hline 5. & 17.945 & 9-octadecanoic acid (Z)- & 0.01 & $\mathrm{C}_{18} \mathrm{H}_{34} \mathrm{O}_{2}$ & 282 & $\begin{array}{l}\text { Antihypertensive, increases } \\
\text { HDL and decrease LDL }\end{array}$ \\
\hline 6. & 21.532 & 2-methyltetracosane & 0.01 & $\mathrm{C}_{25} \mathrm{H}_{52}$ & 352 & Free radical scavenging \\
\hline 7. & 23.423 & $\begin{array}{l}\text { Hexadecanoic acid, } \\
\text { 2-hydroxy-1-(hydroxymethyl) ethyl ester }\end{array}$ & 0.02 & $\mathrm{C}_{19}^{25} \mathrm{H}_{38}^{52} \mathrm{O}_{4}$ & 330 & Antioxidant \\
\hline 8. & 27.575 & Tetratetracontane & 0.09 & $\mathrm{C}_{44} \mathrm{H}_{90}$ & 618 & $\begin{array}{l}\text { Hypoglycemic, antioxidant } \\
\text { activity }\end{array}$ \\
\hline 10. & 37.355 & Stigmasta-5, 22-dien-3-ol & 0.32 & $\mathrm{C}_{29} \mathrm{H}_{48} \mathrm{O}$ & 412 & Synthetic progesterone \\
\hline
\end{tabular}

Table 4: Bioactivity of phytocomponents identified in the hexane extract of stem of Sarcostemma viminale

\begin{tabular}{|c|c|c|c|c|c|c|}
\hline S.No. & RT (minutes) & Name of compound & $\%$ area & $\begin{array}{l}\text { Molecular } \\
\text { formula }\end{array}$ & $\begin{array}{l}\text { Molecular } \\
\text { weight }\end{array}$ & Biological activity \\
\hline 1. & 18.881 & 9,12 -octadecadienoic acid (Z, Z)- & 0.50 & $\mathrm{C}_{18} \mathrm{H}_{32} \mathrm{O}_{2}$ & 280 & $\begin{array}{l}\text { Cancer preventive, insectifuge, } \\
\text { anti-inflammatory, nematicide, } \\
\text { hepatoprotective, antihistaminic, anticancer, } \\
\text { antiarthritic, antieczemic }\end{array}$ \\
\hline 2. & 20.920 & $\begin{array}{l}\text { Cyclobutanecarboxylic acid, } \\
\text { undec-2-enyl ester }\end{array}$ & 0.01 & $\mathrm{C}_{16} \mathrm{H}_{28} \mathrm{O}_{2}$ & 252 & Antimicrobial activity \\
\hline 4. & 24.043 & 1, 2-benzenedicarboxylic acid & 0.02 & $\mathrm{C}_{24}^{25} \mathrm{H}_{38}^{52} \mathrm{O}_{4}$ & 390 & $\begin{array}{l}\text { Antioxidant, antimicrobial, antifouling } \\
\text { activity }\end{array}$ \\
\hline 5. & 28.977 & Tetracontane & 13.12 & $\mathrm{C}_{4} \mathrm{H}_{82}$ & 562 & Anti-inflammatory and analgesic activity \\
\hline 6. & 37.317 & Stigmasterol & 0.57 & $\mathrm{C}_{29}^{4} \mathrm{H}_{48}^{82} \mathrm{O}$ & 412 & $\begin{array}{l}\text { Antimicrobial, antihepatotoxic, antiviral, } \\
\text { antioxidant, anticancer, hypocholesterolemic }\end{array}$ \\
\hline 7. & 40.555 & Beta.-amyrin & 4.36 & $\mathrm{C}_{30} \mathrm{H}_{50} \mathrm{O}$ & 426 & $\begin{array}{l}\text { Antibacterial, antioxidant, } \\
\text { anti-inflammatory, antinociceptive, potential } \\
\text { antiplatelet components, hypoglycemic, } \\
\text { hypolipidemic effects, sedative action, } \\
\text { hepatoprotective activities }\end{array}$ \\
\hline 8. & 42.550 & Lupeol & 8.98 & $\mathrm{C}_{30} \mathrm{H}_{50} \mathrm{O}$ & 426 & $\begin{array}{l}\text { Antimalarial, antioxidant, antiflu, } \\
\text { antihyperglycemic, antitumor, antiviral, } \\
\text { pesticide, cytotoxic anti-inflammatory }\end{array}$ \\
\hline
\end{tabular}

amyrin (18.51\%) and 2-methyltetracosane (0.01\%), eicosanoic acid (0.01\%), 9-octadecenoic acid (Z)- $(0.01 \%)$ were present in minimum amount in the chloroform extract; acetic acid 4, 4, 6A, 8A, 11, 12, 14B-octamethyl-1, 2, 3, 4, 4A, 5, 6, 6A, 6B, 7, 8, 8A, 9, 10, 11, $12,12 \mathrm{~A}, 14,14 \mathrm{~A}, 14 \mathrm{~B}$-eicosahydro-picen-3-YL ester \$ $\$$ URS-12-en-3YL acetate is present maximum amount (45.47\%), followed by. beta.amyrin $(19.21 \%)$ and tetradecanal $(0.01 \%)$, cis-vaccenic acid $(0.01 \%)$, docosane $(0.01 \%)$, eicosanoic acid $(0.01 \%)$, octadecanal $(0.01 \%)$, cyclobututanecarboxylic acid, undec-2-enyl ester $(0.01 \%)$, and 7,9-ditert-butyl-1-oxaspiro(4,5) deca-6,9-diene-2,8-dione $(0.01 \%)$ were present in minimum amount in the hexane extract.
The GC showed the relative concentrations of various compounds getting eluted as a function of retention time. The height of peak indicates the relative concentrations of the components present in plants. The mass spectrometer analyses the compounds eluted at different time; identify the nature and structure of the compounds. The larger amount fragments into smaller compounds, giving rise to appearance of peak at different $\mathrm{m} / \mathrm{z}$ ratio. These mass spectra are fingerprint of that compounds which can be identified from the data library. The GC-MS analysis of $S$. viminale (L.) R. Br. with all the three solvents may open an innovative platform to design more herbal formulations. Methanol and chloroform were proved to be better solvents as compared to hexane. 


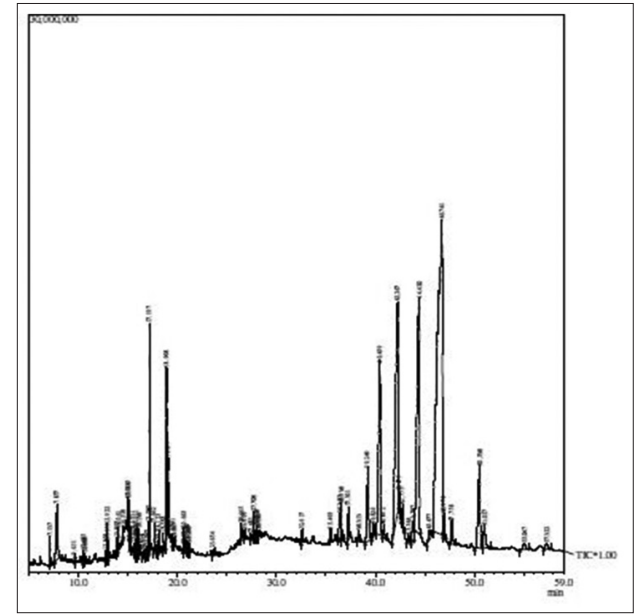

Fig. 1: Gas chromatography-mass spectrometry chromatogram of the methanolic extract of stem of Sarcostemma viminale

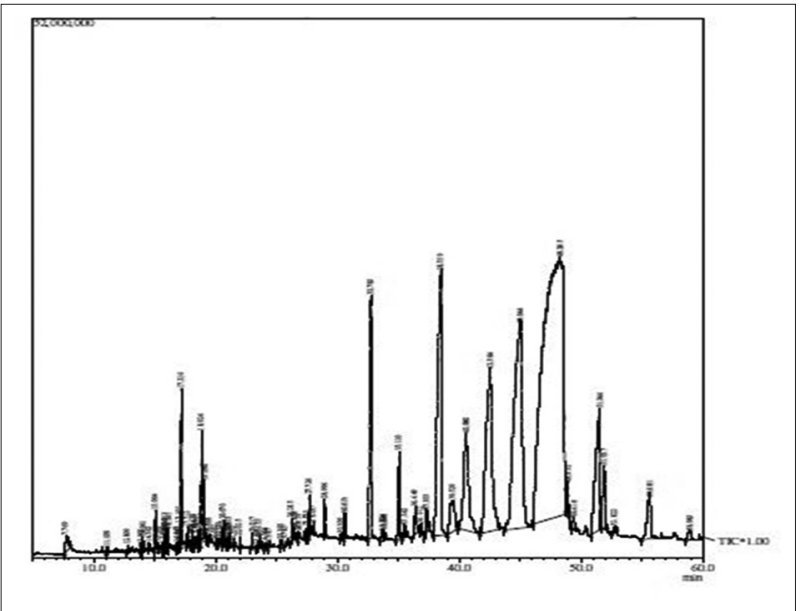

Fig. 2: Gas chromatography-mass spectrometry chromatogram of the chloroform extract of stem of Sarcostemma viminale

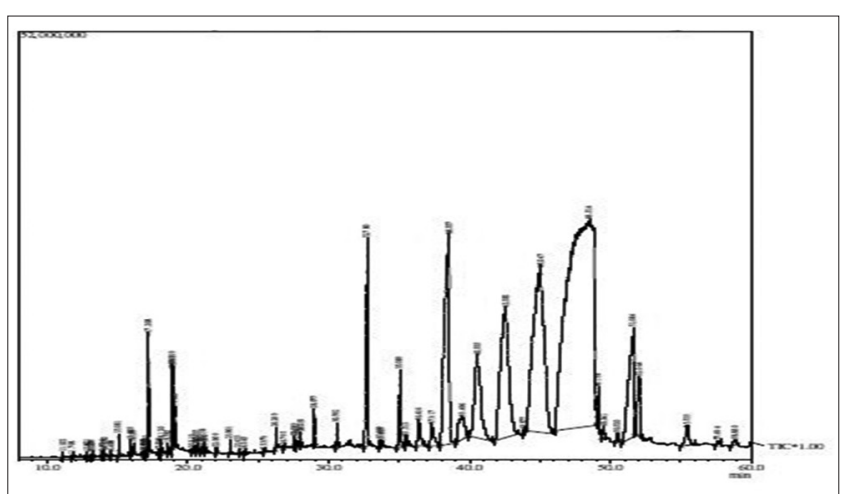

Fig. 3: Gas chromatography-mass spectrometry chromatogram of the hexane extract of stem of Sarcostemma viminale

\section{CONCLUSION}

This is the first report, where we have analyzed so many bioactive compounds using GC-MS analysis. The compound shows antifungal, antibacterial, antioxidant, anticancerous, antiaging, and antiinflammatory properties. Plant-derived bioactive phytocompounds can be used for herbal drug formulations. This valuable bioactive compound justifies the use of the stem of this plant for the treatment of various ailments by traditional practitioners. As the plant is endangered, first of all, it requires proper strategies for its in situ as well as ex situ conservation. Further research is required as far as ethico-legal issues are concerned.

\section{ACKNOWLEDGMENT}

The authors are thankful to AIRF, JNU, Delhi and CAS Department of Botany, JNVU, Jodhpur, Rajasthan for providing infrastructure and technical support.

\section{REFERENCES}

1. Sheela D, Uthayakumari F. GC-MS analysis of bioactive constituents from coastal sand Dune taxon-Sesuvium portulacastrum. Biosci Discov 2013;4(1):47-53.

2. Jagtap NS, Khadabadi SS, Ghorpade DS, Banarase NB, Naphade SS. Antimicrobial and antifungal activity of Centella asiatica (L.) Urban Umbeliferae. Res J Pharm Technol 2009;2(2):328-30.

3. Vanitha V, Umadevi KJ, Vijayalakshmi K. Determination of bioactive components of Annona squamosa L leaf by GC-MS analysis. Int J Pharm Sci Drug Res 2011;3(4):309-12.

4. Nagavani V, Rao TR. Evaluation of antioxidant potential and qualitative analysis of major polyphenols by RP-HPLC in Nynphaea nouchali Burm. Int J Pharm Pharm Sci 2010;2(4):98-104.

5. Dhivya R, Manimegalai K. Preliminary phytochemical screening and GC-MS profiling of ethanolic flower extract of Calotropis gigantea Linn. (Apocynaceae). J Pharmacogn Phytochem 2013;2(3):28-32.

6. Arora S, Meena S. Qualitative preliminary phytochemical screening and GC-MS analysis of root of Sarcostemma viminale (L.) R. Br., An endangered plant. Int J Pharm Res Biosci 2016;5(2):89-100.

7. Meve U, Lied-Schumann S. Taxonomic dissolution of Sarcostemma (Apocynaceae: Asclepiadoideae). Kew Bull 2012;67(4):751-8.

8. Mohammed S, Kasera PK, Shukla JK. Unexploited plants of potential medicinal value from the Indian Thar desert. Nat Prod Rad 2004;3(2):69-74

9. Ray S, Sheikh M, Mishra S. Ethanomedicinal plants used by tribals of East Nimar Madhya Pradesh. Indian J Tradit Knowl 2011;10(2):367-71.

10. Patil DA. Indian ethnomedicines: Origins in the perspective of doctrine of signature. Life Sci Lealf 2012;1:6-15.

11. Helen PA, Aswathy MR, Deepthi KG, Rathi RM, Joseph JJ, Sree SJ. Phytochemical analysis and anticancer activity of leaf extract of Mangifera indica (Kottukonam Varika). Int J Pharm Sci Res 2013;2(3):819-24.

12. Ruthiran P, Lokesh R, Chinnadurai IS. Phytochemical studies and GCMS analysis of Spermadictyon suaveolens Roxb. Int J Pharm Pharm Sci 2017;9(3):143-9.

13. Hammed IH, Lena FH, Sabreen AK. Analysis of bioactive chemical compounds of Aspergillus niger by using gas chromatographymass spectrometry and Fourier-transform infrared spectroscopy. J Pharmacogn Phytother 2015;7(8):132-63.

14. Dhivya SM, Kalaichelvi K. UV-visible spectroscopic and FTIR analysis of Sarcostemma brevistigma, wight. and arn. Int J Curr Pharm Res 2017;9(3):46-9.

15. Grover N, Patni V. Phytochemical characterization using various solvent extracts and GC-MS analysis of methanolic extract of Woodfordia fruticosa (L) Kurz. leaves. Int J Pharm Pharm Sci 2013;5(4):291-5. 